\title{
Crm-A, bcl-2 and NDGA inhibit CD95L-induced apoptosis of malignant glioma cells at the level of caspase 8 processing
}

\author{
Bettina Wagenknecht ${ }^{1}$, Jörg B. Schulz ${ }^{1}$, Erich Gulbins ${ }^{2}$ and \\ Michael Weller ${ }^{1,3}$ \\ ${ }^{1}$ Laboratory of Molecular Neuro-Oncology, Department of Neurology, \\ University of Tübingen, School of Medicine, Tübingen, Germany \\ 2 Institute of Physiology, University of Tübingen, School of Medicine, Tübingen, \\ Germany \\ ${ }^{3}$ corresponding author: Michael Weller, M.D., Department of Neurology, \\ University of Tübingen, School of Medicine, Hoppe-Seyler-Strasse 3, 72076 \\ Tübingen, Germany. tel: 497071298 2141; fax: 49707129 6507; \\ e-mail: michael.weller@uni.tuebingen.de
}

Received 17.11.97; revised 13.5.98; accepted 24.6.98 Edited by M. Piacentini

\begin{abstract}
Susceptibility to CD95 (Fas/APO-1)-mediated apoptosis in human glioma cells depends on CD95 expression and unknown factors that regulate signal transduction. Thus, $\mathrm{LN}-18$ cells are highly sensitive to CD95 ligand (CD95L) whereas LN-229 cells require coexposure to inhibitors of RNA or protein synthesis for induction of apoptosis. Here, we report that caspase 8 and 3 activation, poly(ADP-ribose)polymerase cleavage and apoptosis are inhibited by the lipoxygenase inhibitor, nordihydroguaretic acid (NDGA), or ectopic expression of crm-A or bcl-2. CD95L-induced glioma cell apoptosis does not involve ceramide generation. Apoptosis induced by exogenous ceramide resembles CD95-mediated apoptosis in that bcl-2 is protective but differs in that NDGA and crm-A have no effect and in that cycloheximide (CHX) inhibits rather than potentiates ceramide-induced cell death. We conclude that caspase 8 and caspase 3 activation, but not ceramide generation, are required for CD95 ligand-induced apoptosis of glioma cells and that bcl-2, crm-A and NDGA all act upstream of caspases to inhibit apoptosis.
\end{abstract}

Keywords: glioma; CD95 (APO-1/Fas); apoptosis; caspases; NDGA

Abbreviations: CD95L: CD95 ligand; Ac-YVAD-CMK: acetyl-TyrVal-Ala-Asp-chloromethylketone; Ac-DEVD-CHO: acetyl-Asp-GluVal-Asp-aldehyde; CHX: cycloheximide; ICE: interleukin-1 $\beta$ converting enzyme (caspase-1); NDGA: nordihydroguaretic acid; PARP: poly(ADP-ribose)polymerase

\section{Introduction}

CD95 (Fas/APO-1) is a $48 \mathrm{kDa}$ transmembrane receptor protein of the nerve growth factor/tumor ecrosis factor receptor superfamily. Activation of the receptor by its endogenous ligand, CD95L, triggers apoptosis in susceptible target cells. CD95-dependent signaling involves FADD/ MORT1 (Fas-associating protein with death domain) which binds to an interleukin 1-converting enzyme (ICE)-like protease, caspase 8/FLICE (FADD-like ICE), an upstream component of a proteolytic cascade consisting of other proteases including caspase 3/CPP32 (Chinnaiyan et al, 1995; Kischkel et al, 1995; Muzio et al, 1996; Srinivasula et al, 1996). Caspase activation is an essential step in the CD95 signaling pathway since ectopic expression of the poxvirusderived serpin crm-A or pseudosubstrate caspase inhibitors confer protection from the cytotoxic effects of agonistic CD95 antibodies or CD95L (Tewari and Dixit, 1995; Los et al, 1995; Hasegawa et al, 1996; Schlegel et al, 1996). CD95 signaling may also involve ceramide generation induced by the activation of acidic or neutral sphingomyelinase (Cifone et al, 1995; Tepper et al, 1995; Hannun, 1996). Whether ceramide generation is downstream (Gamen et al, 1996) or upstream (Mizushima et al, 1996) of caspase activation, has remained unclear.

CD95-mediated apoptosis is a novel therapeutic target for human malignant glioma (Weller et al, 1994). CD95Linduced apoptosis of these cells is inhibited by ectopic expression of bcl-2 and by the lipoxygenase inhibitor, NDGA (Weller et al, 1995; Wagenknecht et al, 1997). Here, we examined the role of caspase activation and ceramide generation and their modulation by crm-A, bcl-2 and NDGA during CD95L-induced apoptosis of human malignant glioma cells.

\section{Results}

CD95L induces caspase 8 and 3 processing and PARP cleavage in human malignant glioma cells

LN-18 and LN-229 human malignant glioma cell lines were selected for this study. Bcl-2-expressing sublines have been described (Weller et al, 1995). Crm-A-expressing sublines were generated to study the role of caspases (Figure 1). LN18 cells are highly sensitive to CD95-mediated apoptosis. LN229 cells require coexposure to CD95L and inhibitors of RNA or protein synthesis such as actinomycin $\mathrm{D}$ or $\mathrm{CHX}$ for induction of apoptosis (Wagenknecht et al, 1997). Exposure of these cells to CD95L (LN-18) or CD95L plus CHX (LN-229) induced time-dependent caspase 8 and caspase 3 processing as assessed by immunoblot analysis (Figure $2 \mathrm{~A}$ ), and caspase 3 -like protease activity as assessed by DEVD-AMC cleavage (Figure $2 \mathrm{C}$ ). No caspase 8 or 3 -like activity was detected in CD95L-treated LN-229 cells in the absence of $\mathrm{CHX}$ (Figure 2A and C). Caspase 1 was expressed by $\mathrm{LN}-18$ and LN-229 cells but, during CD95L-induced apoptosis, caspase-1 levels did not decrease, nor was their cleavage of caspase-1, nor was caspase 1-like protease activity detected as assessed by cleavage of DABCYL-YVADAPV- 


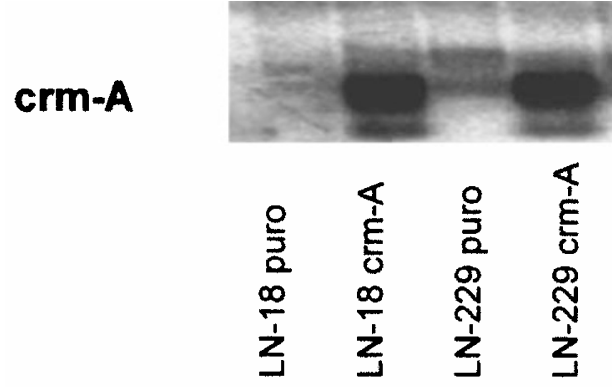

Figure 1 Generation of crm-A-expressing LN-18 and LN-229 sublines. LN-18 and $\mathrm{LN}-229$ cells were transfected with the crm-A expression plasmid or a puro control vector. Crm-A mRNA expression was assessed by Northern blot analysis as described in Materials and Methods. Equal RNA loading was ascertained by methylene blue staining (not shown)

EDANS, a selective substrate for caspase-1 at $20 \mu \mathrm{M}$ concentrations (Pennington and Thornberry, 1994; data not shown). PARP is a substrate for caspase-mediated proteolytic cleavage in several types of apoptotic cell death (Gu et al, 1995; Casciola-Rosen et al, 1996). Here, CD95L induced cleavage of the $113 \mathrm{kDa}$ PARP molecule into $85 \mathrm{kDa}$ fragments starting at $4 \mathrm{~h}$ in $\mathrm{CHX}$-exposed $\mathrm{LN}-229$ cells (Figure 2B), consistent with the time course of CD95Linduced caspase activity (Figure 2C). As shown for caspase 3 activation, CD95L alone did not induce PARP cleavage in LN229 but in LN-18 cells (data not shown).

CD95L-induced caspase 3-like activity was blocked by the caspase inhibitors, Ac-YVAD-CMK and Ac-DEVD-CHO, at concentrations previously shown to inhibit caspase 3 (Gamen et al, 1996; Mizushima et al, 1996; Lazebnik et al, 1994) and by ectopic expression of crm-A (Figure 2D). Prevention of caspase activity in CD95L-treated glioma cells was associated with inhibition of cell death (Figure $2 \mathrm{E}-\mathrm{F}$ ), confirming that caspase activation is an essential step, and not an epiphenomenon, in CD95L-induced apoptosis of human malignant glioma cells, as previously reported for various non-glial cells (Tewari and Dixit, 1995; Los et al, 1995; Enari et al, 1995). To assess the specific step of interception of the apoptotic cascade in crm-Atransfected cells, we monitored the cleavage of caspase 8 and caspase 3 during CD95L-induced apoptosis in crm-A cells versus puro control cells. Figure $2 \mathrm{G}-\mathrm{H}$ shows that crm-A blocked caspase 8 processing as well as caspase 3 processing, thus, at an upstream event of CD95L-induced signaling.

\section{Caspase 8 and 3 processing and PARP cleavage are inhibited by the lipoxygenase inhibitor, NDGA and extopic expression of bcl-2}

Exposure to NDGA or ectopic expression of bcl-2 attenuate CD95L-induced apoptosis of human malignant glioma cells (Weller et al, 1995; Wagenknecht et al, 1997). Here, we asked whether NDGA and bcl-2 interfere with the killing pathway upstream or downstream of caspase activation and PARP cleavage. Either exposure to NDGA or ectopic expression of bcl-2 inhibited caspase 8 and 3 processing as well as PARP cleavage (Figure 3A). As expected, PARP cleavage was also prevented when the glioma cells were treated with the caspase inhibitor, Ac-YVAD-CMK (data not shown). Further, NDGA and bcl-2 inhibited activation of caspase 3 as assessed by Ac-DEVD-AMC cleavage in both cell lines (Figure $3 \mathrm{~B}$ and $\mathrm{C}$ ). Consistent with an upstream NDGAsensitive step in CD95L-induced apoptosis, NDGA had to be added within 2-4 $\mathrm{h}$ of CD95L exposure to block apoptosis (Figure 3D). DNA fragmentation is a rather late event during CD95L-induced apoptosis (Wagenknecht et al, 1997). Accordingly, exposure to NDGA or ectopic expression of bcl-2 and crm-A prevented CD95L-induced DNA fragmentation (Figure 3E).

\section{No ceramide release during CD95L-induced glioma cell apoptosis}

Several studies in nonglial cell lines have suggested a crucial role for ceramide release in CD95L-induced apoptosis (Cifone et al, 1995; Hannun, 1996). In contrast, we find that CD95L did not induce the formation of ceramide in $\mathrm{LN}-18$ or $\mathrm{LN}-229$ either in the absence or presence of $\mathrm{CHX}$ (Figure 4A). As a positive control, we confirm a significant increase of ceramide in L929 fibrosarcoma cells exposed to TNF- $\alpha$ (Jayadev et al, 1997). Consistent with this negative finding in glioma cells, we observed that inhibitors of acid sphingomyelinase such as desipramine (Hurwitz et al, 1994) or of ceramide synthase such as fumonisin $B_{1}$ (Bose et al, 1995), that is, of the key enzymes involved in ceramide generation, had no effect on CD95L-induced apoptosis. In contrast, desipramine, but not fumonisin $B_{1}$, almost completely blocked TNF- $\alpha$-induced apoptosis of L929 cells (Figure 4B), confirming that ceramide in this paradigm is derived from acid sphingomyelinase. Finally, we examined the effects of ceramide $(50 \mu \mathrm{M})$ when added exogenously to the glioma cells (Figure $4 \mathrm{C}$ and D). We find that ceramide-induced glioma cell killing is not blocked by NDGA, caspase inhibitors, or ectopic expression of crm-A. In contrast, coexposure to $\mathrm{CHX}$, or ectopic expression of bcl-2, attenuated ceramide toxicity in both cell lines.

\section{Discussion}

The CD95/CD95L system plays a key role in the peripheral control of the immune response and has recently been implicated in maintaining immune privilege in privileged sites such as eye, testis and brain. Another area of intense research in the CD95/CD95L system involves tumor host interactions. In that regard, malignant glioma is of specific interest since its local invasive growth and lack of metastasis make a locoregionary treatment approach that targets CD95 promising (Weller et al, 1994). Yet, the role of the CD95/ CD95L system and has been further complicated in that these cells coexpress functional CD95 and CD95L without undergoing suicidal or fratricidal apoptosis (Weller et al, 1998). Therefore, understanding the CD95-dependent killing cascade in glioma cells is of significant theoretical and clinical interest.

We confirm that caspase 8 and 3 activation are critical steps in the killing cascade triggered by CD95/CD95L interactions (Tewari and Dixit, 1995; Los et al, 1995; Enari 
A

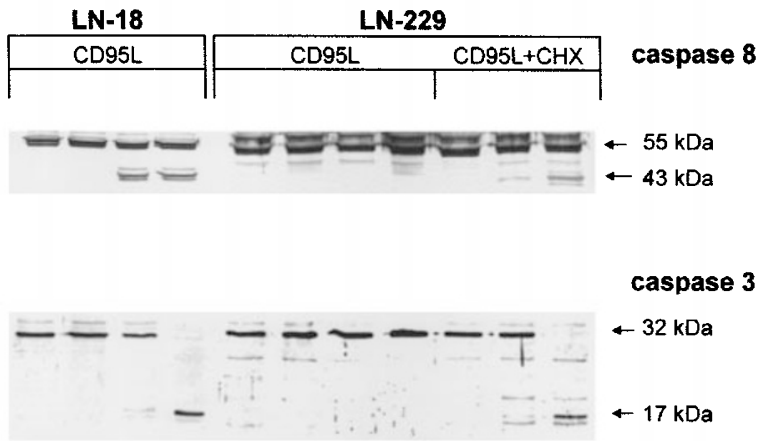

B

PARP

$0 \quad 1 \mathrm{~h} \quad 2 \mathrm{~h} \quad 4 \mathrm{~h} \quad 6 \mathrm{~h} \quad 8 \mathrm{~h}$

$113 \mathrm{kDa} \rightarrow \mathrm{Ed} \longrightarrow+\cdots$

$85 \mathrm{kDa}$

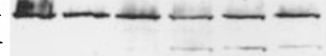

G

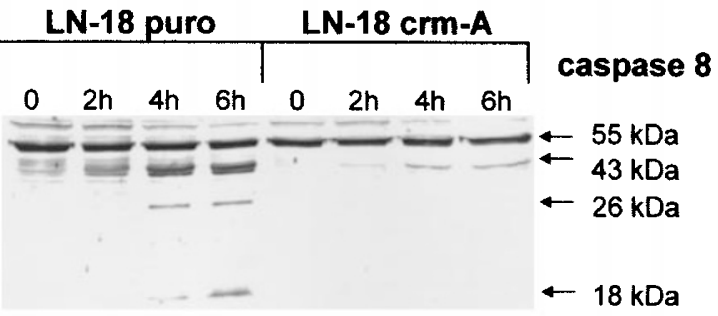

caspase 3
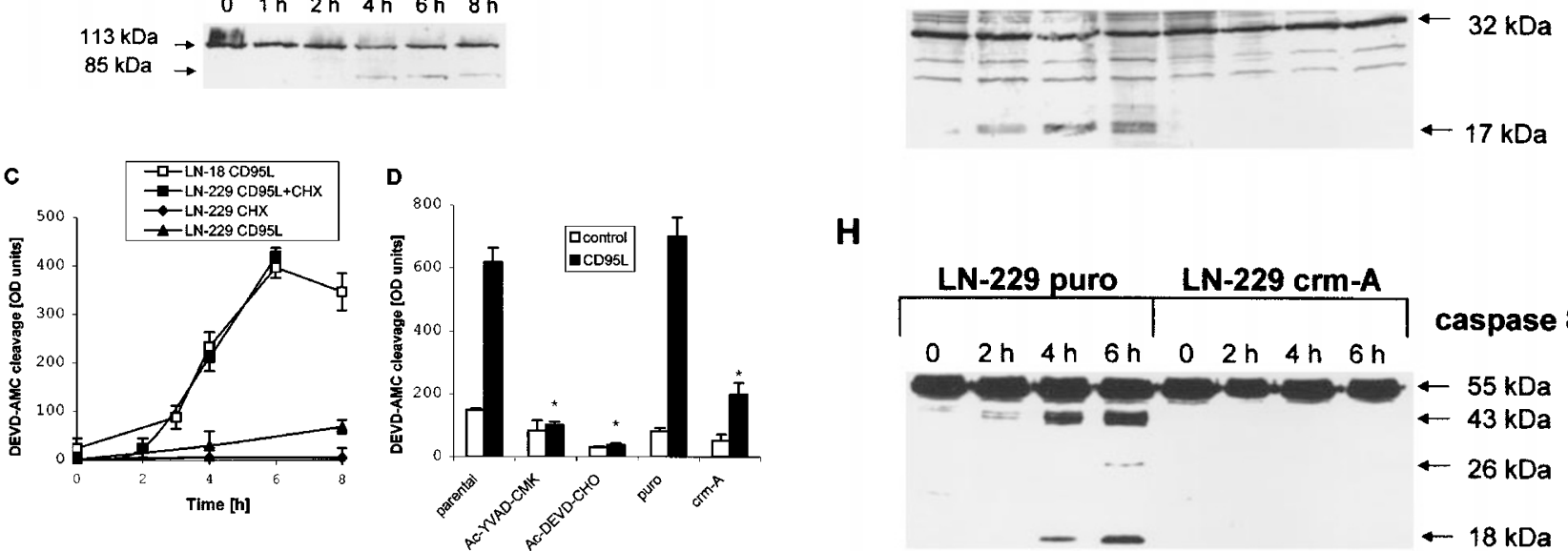

H
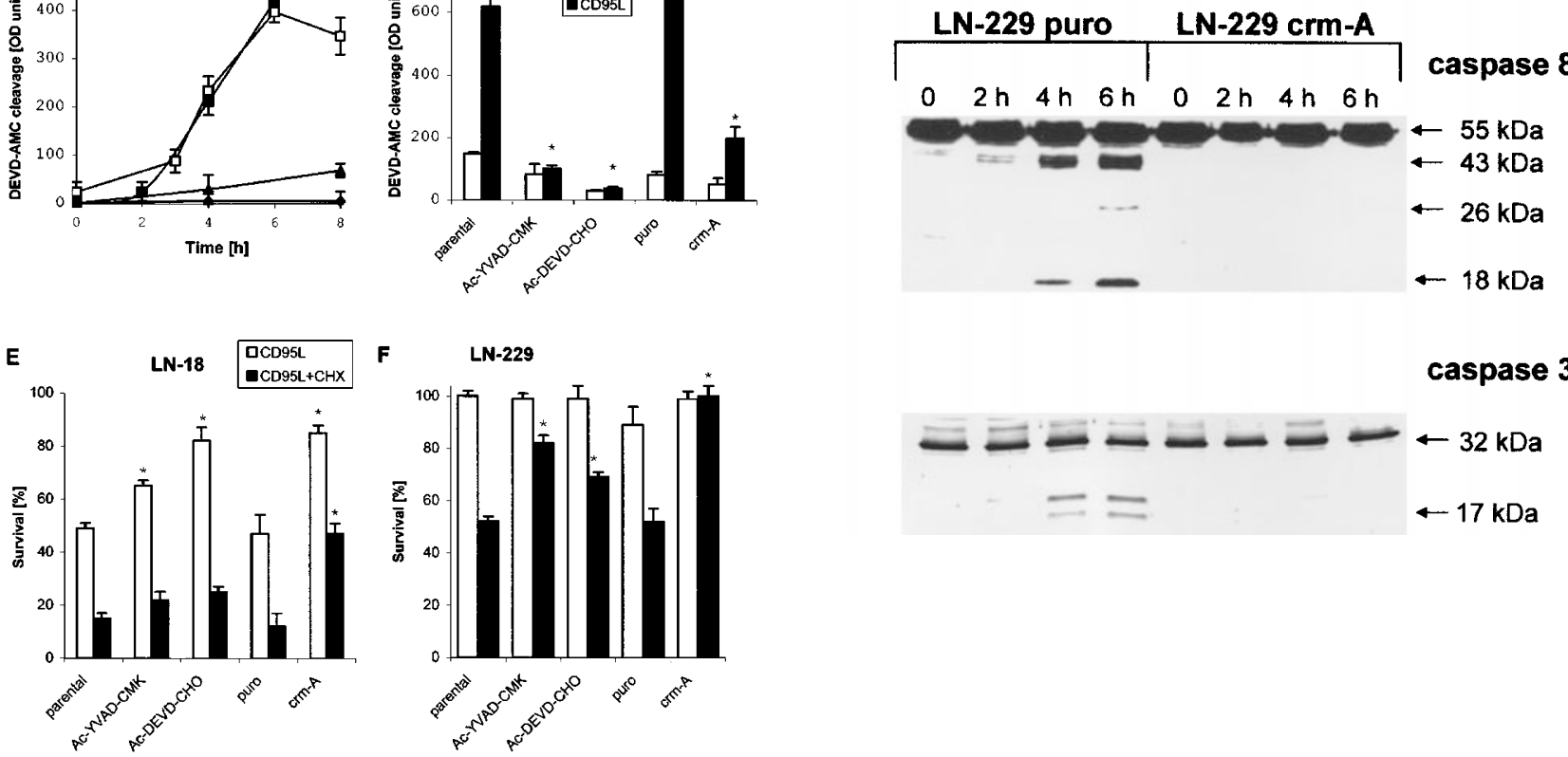

caspase 3

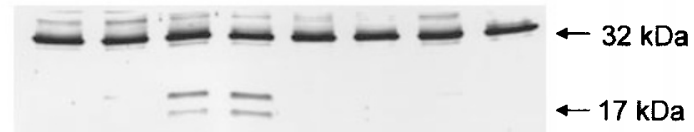

Figure 2 Caspase 3 activation during CD95L-induced apoptosis of human malignant glioma cells. (A) LN-18 or LN-229 cells were exposed to CD95L (60 U/ml) in the absence $(\mathrm{LN}-18, \mathrm{LN}-229)$ or presence $(\mathrm{LN}-229)$ of $\mathrm{CHX}(10 \mu \mathrm{g} / \mathrm{ml})$ for various lengths of time. Immunoblot analysis of caspase 8 and caspase 3 was performed as described in Materials and Methods. Activation of caspase 8 is reflected by the occurrence of $43 \mathrm{kDa}$ proteolytic product. Activation of caspase 3 is reflected by a gradual decrease of caspase $3 / \mathrm{p} 32$ and the time-dependent occurrence of caspase 3/p17. (B) LN-229 cells were either untreated or exposed to CD95L (60 U/ml) plus $\mathrm{CHX}(10 \mu \mathrm{g} / \mathrm{ml})$ for $0-8 \mathrm{~h}$. Immunoblot analysis was performed as described. (C) Caspase 3 -like enzymatic activity was determined in the same experimental setting by fluorimetric quantification of Ac-DEVD-AMC cleavage as described in Materials and Methods (LN-18, open squares; LN-229, CHX alone filled rhomboids; CD95L alone, filled triangles; CD95L plus CHX, filled squares). (D) LN-18 cells were preincubated with the caspase inhibitors, Ac-YVAD-CMK (200 $\mu \mathrm{M})$ or AcDEVD-CHO $(600 \mu \mathrm{M})$ for $1 \mathrm{~h}$ and subsequently exposed to CD95L $(60 \mathrm{U} / \mathrm{ml})$ for $6 \mathrm{~h}$ in the presence or absence of the inhibitors. Further, crm-A or puro control LN-18 transfectants were exposed to CD95 $(60 \mathrm{U} / \mathrm{ml})$ in parallel. Caspase 3 activity was measured as in (C). Similar results were obtained in $\mathrm{LN}-229$ cells (data not shown). Data in (C) and (D) are expressed as OD units (mean and S.D., $n=5,{ }^{*} P<0.05, t$-test, caspase inhibitors or crm-A compared with respective controls). (E,F) $\mathrm{LN}-18(\mathrm{E})$ or $\mathrm{LN}-229(\mathrm{~F})$ cells were either untreated or preexposed to the caspase inhibitors for $1 \mathrm{~h}$ and then exposed for $16 \mathrm{~h}$ to $\mathrm{CD} 95 \mathrm{~L}(60 \mathrm{U} / \mathrm{ml})$ alone or to $\mathrm{CD} 95 \mathrm{~L}$ $(60 \mathrm{U} / \mathrm{ml})$ plus $\mathrm{CHX}(10 \mu \mathrm{g} / \mathrm{ml})$ in the absence or presence of the inhibitors. Crm-A and puro transfectants were also tested for susceptibility to CD95L-induced cell death. Viability was measured by crystal violet assay. Data are expressed as mean percentages of survival and S.D. compared with controls exposed to control supernatant, in the absence or presence of the inhibitors or $\mathrm{CHX}\left(n=3,{ }^{*} P<0.05, t\right.$-test). $(\mathbf{G}, \mathrm{H}) \mathrm{LN}-18(\mathrm{G})$ or $\mathrm{LN}-229(\mathrm{H})$ puro or crm-A-transfected cells were exposed to $\mathrm{CD} 95 \mathrm{~L}(60 \mathrm{U} / \mathrm{ml})$ in the presence of $\mathrm{CHX}(10 \mu \mathrm{g} / \mathrm{ml})$. Caspase 8 (upper panel) or caspase 3 (lower panel) cleavage were analyzed by immunoblot analysis as described in Materials and Methods. Three caspase 8 protolytic products of 43, 26 and $18 \mathrm{kDa}$ become apparent 
A

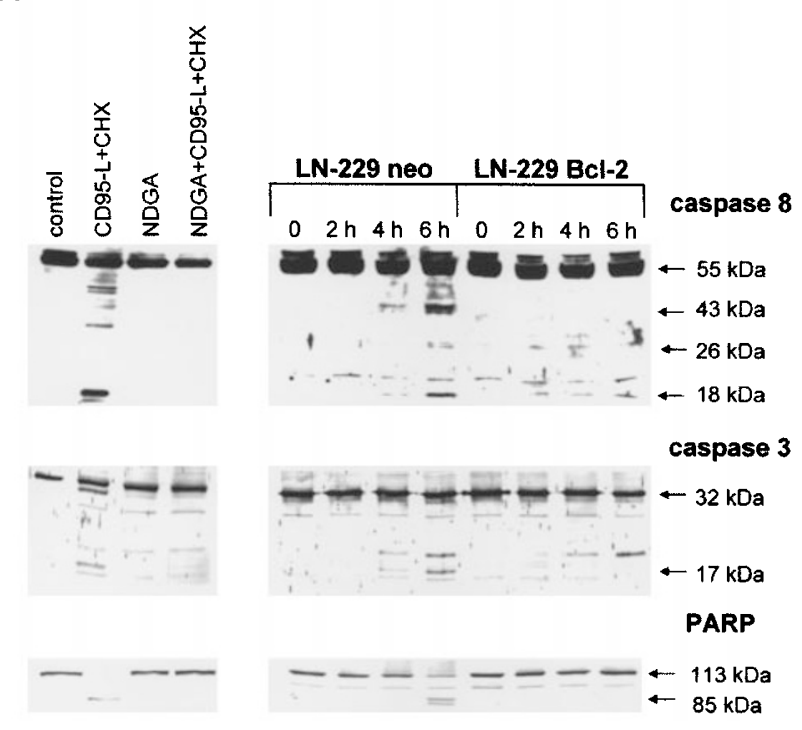

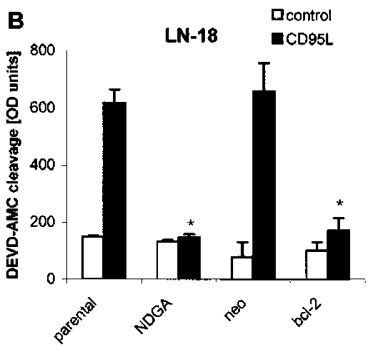
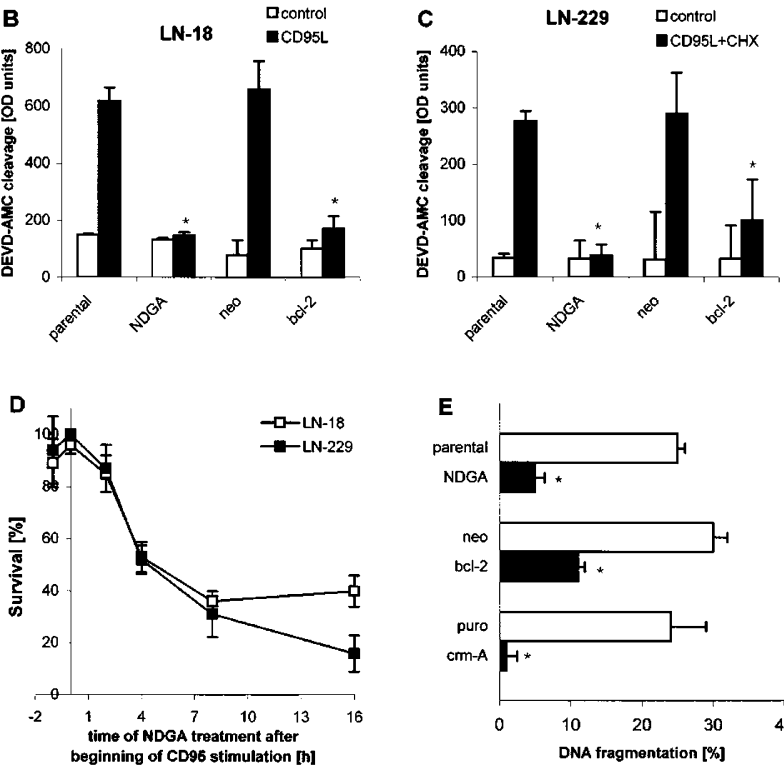

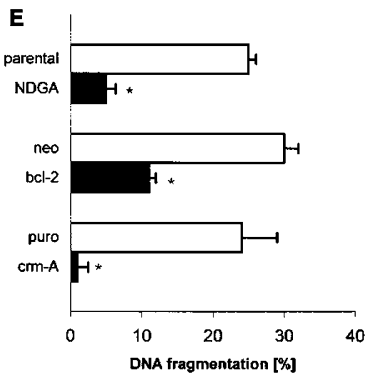

Figure 3 NDGA and ectopic expression of bcl-2 inhibit CD95L-induced apoptosis upstream of caspase activation and PARP cleavage. (A) On the left, LN-229 cells were pretreated with NDGA $(30 \mu \mathrm{M})$ for $1 \mathrm{~h}$ and then exposed for $6 \mathrm{~h}$ to CD95 $(60 \mathrm{U} / \mathrm{ml})$ plus CHX $(10 \mu \mathrm{g} / \mathrm{ml})$. In the middle and on the right, neo control or Bcl2-transfected LN-229 cells were exposed to CD95L in the presence of $\mathrm{CHX}$ for the indicated lengths of time. Caspase 8 (upper panel), caspase 3 (middle panel) or PARP (lower panel) cleavage were analyzed by immunoblot analysis. (B,C) LN-18 (B) or LN-229 (C) cells were exposed to CD95L (60 U/ml) in the absence (LN-18) or presence (LN-229) of $\mathrm{CHX}(10 \mu \mathrm{g} / \mathrm{ml})$ for $6 \mathrm{~h}$. Caspase 3 activity was measured as in Figure $2 \mathrm{C}\left({ }^{*} P<0.05, t\right.$-test, protection mediated by NDGA or bcl-2). We examined the effects of coexposure to NDGA $(30 \mu \mathrm{M})$ and CD95 in parental cells or compared bcl-2 transfectants with neo control cells. (D) $\mathrm{LN}-18$ (open squares) or LN-229 (filled squares) were treated with CD95L in the absence (LN-18) or presence (LN-229) of CHX for $16 \mathrm{~h}$. NDGA (30 $\mu \mathrm{M})$ was added at the indicated time points after CD95L exposure. Survival was assessed by crystal violet staining. Data are expresed as mean percentage of survival and S.D. ( $n=3$ ) compared with controls exposed to neo control supernatant with NDGA alone. (E) LN-229 cells were untreated or pretreated with NDGA ( $30 \mu \mathrm{M})$ for $1 \mathrm{~h}$ and then exposed to CD95L $(60 \mathrm{U} / \mathrm{ml})$ for $16 \mathrm{~h}$ in the presence of $\mathrm{CHX}(10 \mu \mathrm{g} / \mathrm{ml})$ and in the absence or presence of NDGA. In the same experiment, bcl-2-transfected or neo control cells and crm-A or puro control cells were also treated with CD95L plus CHX. DNA fragmentation were determined as described (Weller et al, 1995). Data are expressed as mean percentages and S.D. ( $n=3,{ }^{*} P<0.05$, prevention of DNA fragmentation by NDGA or bcl-2 or crm-A compared with respective controls)

et al, 1995; Muzio et al, 1996; Medema et al, 1997). Cell death ensued whenever caspase activation was detected, and all pharmacological (NDGA) or genetic (bcl-2, crm-A) manipulations that inhibited apoptosis did so at the level of, or upstream of, caspase activation. Since caspase 8 or 3 were not induced by CD95L in the absence of $\mathrm{CHX}$ in LN229 cells (Figure 2A), the cytoprotective proteins responsible for resistance to cytotoxic cytokines in the absence of macromolecular inhibitors seem to act upstream of caspase activation.

Prevention of caspase activation by bcl-2 has emerged as a common finding in numerous paradigms of apoptosis (Boulakia et al, 1996; Mandal et al, 1996; Chinnaiyan et al, 1996; Smyth et al, 1996). Here, bcl-2-mediated attenuation of CD95L-induced apoptosis of glioma cells was linked to prevention of caspase 8 and 3 activation, too (Figure $3 A$ ). Although in vitro studies predict that crm-A preferentially inhibits caspase 8 rather than caspase 3 (Zhou et al, 1997), the parallel activation of both enzymes during CD95Linduced apoptosis of glioma cells (Figure 3A) precludes conclusions on the precise target of crm-A-mediated protection from apoptosis.

Similar to bcl-2 and crm-A, NDGA inhibited the death cascade upstream of caspase 8 and 3 activation. The precise target of NDGA remains unknown. Lipoxygenase is still the major candidate since antioxidant actions of NDGA during CD95-mediated apoptosis have been excluded (Wagenknecht et al, 1997). Previously, a similar role of lipoxygenase metabolites in TNF-mediated-toxicity of L929 fibrosarcoma cells had been established by O'Donnell et al (1995). The NDGA-sensitive step in CD95-mediated apoptosis may be specific to glioma cells since CD95-transfected L929 cells were not protected from apoptosis by NDGA (SchulzeOsthoff et al, 1994).

There was no significant increase in ceramide levels during CD95L-induced apoptosis (Figure 4A), and no modulation of cell death by inhibitors of acid sphingomyelinase or ceramide synthase (Figure 4B), suggesting that ceramide is not required for CD95L-induced apoptosis of human glioma cells. Although the toxicity of exogenous ceramide and CD95L-induced apoptosis were both attenuated by bcl-2, CHX potentiated CD95L-induced apoptosis but blocked ceramide toxicity (Figure $4 \mathrm{C}$ and $D)$, suggesting that cytoprotective proteins interfere with the CD95 apoptotic pathway whereas new protein synthesis is required for ceramide toxicity in glioma cells. Thus, ceramide may play a central role in CD95-mediated apoptosis of lymphoid cells (Tepper et al, 1995) but not of glioma cells. Further, since bcl-2 inhibited ceramideinduced cell death in the absence of caspase activity, there 

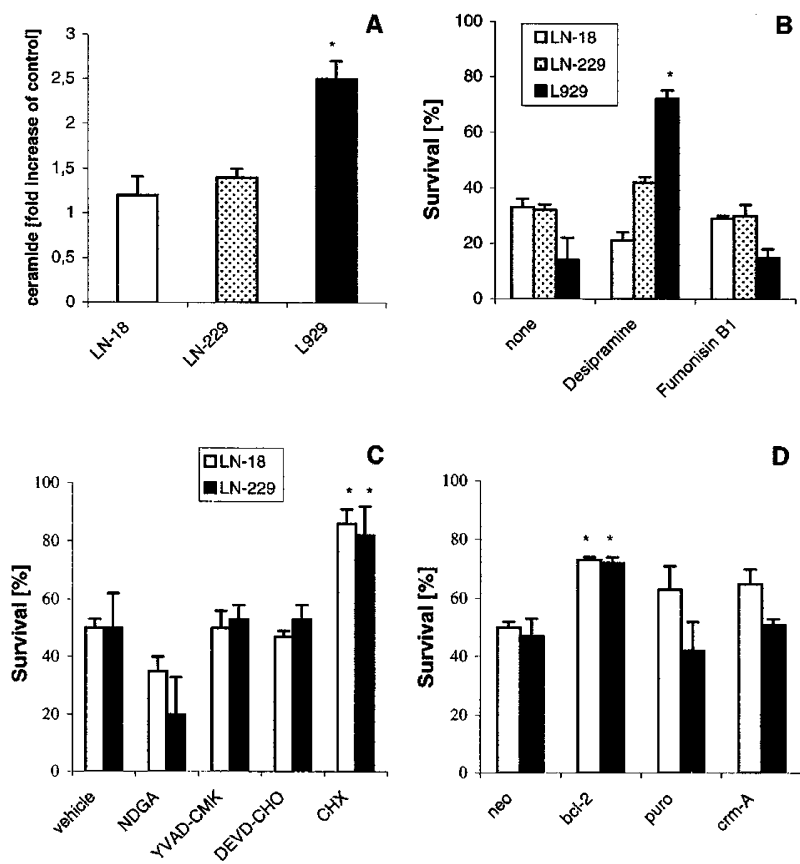

Figure 4 CD95L-induced glioma cell apoptosis: no role for ceramide. (A) The cells were untreated or exposed to CD95L $(60 \mathrm{U} / \mathrm{ml})$ in the absence $(\mathrm{LN}-18)$ or presence of $\mathrm{CHX}(10 \mu \mathrm{g} / \mathrm{ml}, \mathrm{LN}-229)$. L929 cells were treated with TNF- $\alpha$ $(10 \mathrm{ng} / \mathrm{ml})$ in the presence of $\mathrm{CHX}(10 \mu \mathrm{g} / \mathrm{ml})$. Lipids were extracted at $6 \mathrm{~h}$. Ceramide levels were measured as described in Materials and Methods. Data are expressed as $\mathrm{X}$-fold increases over untreated cells (LN-18) or cells treated with $\mathrm{CHX}$ alone (LN-229, L929) $\left(n=3,{ }^{*} P<0.05, t\right.$-test). (B) The cells were not pretreated or pretreated with desipramine $(250 \mu \mathrm{M})$ or fumonisin $\mathrm{B}_{1}(100 \mu \mathrm{M})$ for $1 \mathrm{~h}$. LN-18 cells were then exposed to CD95L $(60 \mathrm{U} / \mathrm{ml})$ alone, $\mathrm{LN}-229$ to CD95L $(60 \mathrm{U} / \mathrm{ml})$ plus CHX $(10 \mu \mathrm{g} / \mathrm{ml})$, L929 cells to TNF- $\alpha(10 \mathrm{ng} / \mathrm{ml})$ plus CHX $(10 \mu \mathrm{g} / \mathrm{ml})$. Viability was measured by crystal violet assay at $16 \mathrm{~h}$. Data are expressed as mean percentage and S.D. of survival compared with controls exposed to the same reagents in the absence of CD95L or TNF- $\alpha(n=3$, ${ }^{*} P<0.05, t$-test). (C) LN-18 (open bars) or LN-229 (black bars) cells were not pretreated (vehicle) or pretreated with NDGA $(30 \mu \mathrm{M})$, Ac-YVAD-CMK $(200 \mu \mathrm{M})$, AC-DEVD-CHO $(600 \mu \mathrm{M})$ or $\mathrm{CHX}(10 \mu \mathrm{g} / \mathrm{ml})$ for $1 \mathrm{~h}$ and subsequently coexposed to these agents and C2-ceramide $(50 \mu \mathrm{M})$ for $16 \mathrm{~h}$. Cytotoxicity was assessed by crystal violet staining. Data are expressed as mean percentages of survival and S.D. $(n=3)$ compared with untreated cells or controls exposed to inhibitors only $\left({ }^{*} P<0.05, t\right.$-test). (D) Bcl-2 or crm-A transfectants, or the respective neo or puro control transfectants, of the LN-18 (open bars) or LN-229 (black bars) cell lines were treated for $16 \mathrm{~h}$ with $\mathrm{C} 2$ ceramide $(50 \mu \mathrm{M})$. Survival was determined by crystal violet staining and expressed as in $(C)\left({ }^{*} P<0.05, t\right.$-test $)$

is more than one biochemical pathway of antiapoptotic action of bcl-2 family proteins in glioma cells (Reed, 1997; Kroemer, 1997).

\section{Materials and Methods}

\section{Chemicals}

$\left[{ }^{32} \mathrm{P}\right]-\gamma$-ATP $(10 \mathrm{mCi} / \mathrm{ml})$ and $\left[{ }^{14} \mathrm{C}\right]$-serine $(50 \mu \mathrm{Ci} / \mathrm{ml})$ were obtained from Amersham (Braunschweig, Germany). NDGA, CHX, Desipramin and Fumonisin $B_{1}$ were purchased from Sigma (St. Louis, MO). AcDEVD-CHO was from Biomol (Hamburg, Germany). DABCYLYVADAPV-EDANS, Ac-YVAD-CMK and AC-DEVD-AMC were ob- tained from Bachem (Heidelberg, Germany). The rabbit polyclonal PARP antibody was obtained from Boehringer (Mannheim, Germany) and the rabbit polyclonal caspase-1 antibody was from Santa Cruz Biotechnology (Santacruz, CA, USA). The caspase 3 antibody (mouse monoclonal) was from Pharmacia (Uppsala, Sweden). The caspase 8 antibody (mouse monoclonal) was kindly provided by Peter $\mathrm{H}$. Krammer (Heidelberg, Germany). The secondary antibodies, antirabbit IgG and anti-mouse IgG, were purchased from Sigma.

\section{Cell lines and cell culture}

The human malignant glioma cell lines LN-18 and LN-229 were kindly provided by Dr. N. de Tribolet (Lausanne, Switzerland) and maintained in DMEM containing 10\% FCS, $2 \mathrm{mM}$ glutamine and penicillin/ streptomycin. L929 cells were kindly provided by Peter H. Krammer. The murine neuroblastoma cell line Neuro-2A was maintained in MEM supplemented with $10 \%$ FCS, $2 \mathrm{mM}$ glutamine, $1 \%$ non-essential amino acids and penicillin/streptomycin. Neuro-2A cells engineered to produce soluble murine CD95L were generated as described (Rensing-Ehl et al, 1995). One unit of cytotoxic activity of CD95L in Neuro-2A supernatants was defined as the activity required for halfmaximal killing of the sensitive glioma cell line, $L N-18$. The experiments using CD95L-containing supernatants were performed using the supernatant from pooled neo vector control cells as control. Glioma cells expressing murine bcl-2 or crm-A were obtained by electroporation (Biorad Gene Pulse, $250 \mathrm{~V}, 950 \mu \mathrm{F}$ ) using the BMG/ bcl-2 (Weller et al, 1995) and pEFR crm-A flag puro plasmids (Strasser et al, 1995). Transgene expression was assessed by immunoblot analysis for murine bcl-2 protein (Weller et al, 1995) and Northern blot analysis for crm-A mRNA (Figure 1). Experiments were performed with control transfectants harbouring plasmids without insert (neo for bcl-2, puro for crm-A).

\section{Assessment of viability and apoptosis}

For cytotoxicity assays, the cells were seeded in 96-well plates $\left(10^{4}\right.$ cells/well) and allowed to attach for $24 \mathrm{~h}$. In some experiments, the cells were preincubated with enzyme inhibitors for $1 \mathrm{~h}$ and then exposed to CD95L for $16 \mathrm{~h}$ in absence or presence of $\mathrm{CHX}$. Growth and viability were assessed by crystal violet staining. DNA fragmentation was measured by quantitative DNA fluorometry (Weller et al, 1997).

\section{Northern blot analysis}

Total RNA was extracted using the RNA purification system (RNeasy, Qiagen, Hilden, Germany) according to the manufacturer's instructions. For Northern analysis, $10 \mu \mathrm{g}$ of total RNA were electrophoresed and transferred to nylon membranes (Hybond N, Amersham, Braunschweig, Germany). Equal loading of RNA was determined by methylen blue staining of rRNA. The filters were hybridized with ${ }^{32} \mathrm{P}$ labelled crm-A cDNA probes. After hybridization, the filters were washed at stringent conditions and bound radioactivity was detected on a phospho-imager using the TINA program (Fuji BasReader 1500, Raytest, Staubenhardt, Germany).

\section{Immunoblot analysis}

Immunoblot studies were performed according to standard procedures (Weller et al, 1994). Briefly, subconfluent glioma cells treated as indicated were scraped off the dishes and harvested in PBS containing phenylmethylsulfonyl-fluoride $(170 \mu \mathrm{g} / \mathrm{ml})$. After centrifugation, cells were resuspended in lysis buffer $(0.05 \mathrm{M} \mathrm{Tris} / \mathrm{HCl} \mathrm{pH} 8.0,0.12 \mathrm{M}$ 
$\mathrm{NaCl}, 5 \mathrm{mM}$ EDTA, 0.5\% NP40, $2 \mu \mathrm{g} / \mathrm{ml}$ aprotinin, $2 \mu \mathrm{g} / \mathrm{ml}$ leupeptin and $120 \mu \mathrm{g} / \mathrm{ml}$ phenymethylsulfonyl fluoride) for $15 \mathrm{~min}$ on ice. Lysates were centrifuged for $10 \mathrm{~min}$ in a microfuge at 13000 r.p.m. and soluble supernatant proteins were used for electrophoresis (20 $\mu \mathrm{g} /$ lane).

\section{Measurement of caspase 3-like protease activity}

Glioma cells were seeded in 96-well plates at a density of $10^{4}$ cells/ well. After stimulation with CD95L, the cells were incubated in lysis buffer (25 mM Tris/HCl pH 8.0, $60 \mathrm{mM} \mathrm{NaCl}, 2.5 \mathrm{mM}$ EDTA, $0.25 \%$ NP40) for $10 \mathrm{~min}$. Then the fluorogenic caspase 3 substrate, AcDEVD-AMC $(12 \mu \mathrm{M})$, was added and the fluorescence determined in $15 \mathrm{~min}$ intervals using $360 \mathrm{~nm}$ excitation and $480 \mathrm{~nm}$ emission wavelengths (CytoFluor 2300).

\section{Determination of ceramide release}

Cells seeded in $10 \mathrm{~cm}^{2}$ dishes were labeled with $\left[{ }^{14} \mathrm{C}\right]$-serine $(0.2 \mu \mathrm{Ci} /$ $\mathrm{ml})$ for $48 \mathrm{~h}$. The cells were washed and stimulatd with CD95L (60 U/ $\mathrm{ml}$ ) in the absence or presence of CHX (LN-18, LN-229), or with TNF- $\alpha$ in the presence of $\mathrm{CHX}$ (L929). Lipids were extracted and separated as described (Tepper et al, 1997). Radioactive lipids were visualized with iodine vapor, and ceramide spots scraped and quantified by liquid scintillation counting. These values were normalized against total lipid extract.

\section{Acknowledgements}

The authors thank C. Grimmel for excellent technical support, A Strasser for pEFR crm-A flag puro, $\mathrm{H}$ Karasuyama and $\mathrm{E}$. Podack for the BMG/bcl2 plasmid, and Peter H. Krammer for the caspase 8 antibody and L929 cells. This study was supported by Deutsche Forschungsgemeinschaft (We 1502/3-2) and the Fortüne-Programm of the University of Tübingen.

\section{References}

Bose R, Verheij M, Haimovitz-Friedman A, Scotto K, Fuks Z and Kolesnick R (1995) Ceramide synthase mediates daunorubicin-induced apoptosis: an alternative mechanism for generating death signals. Cell 82: 405-414

Boulakia CA, Chen G, Ng FW, Teodoro JG, Branton PE, Nicholson DW, Poirier GG and Shore GC (1996) Bcl-2 and adenovirus E1B $19 \mathrm{kDa}$ protein prevent E1Ainduced processing of CPP32 and cleavage of poly(ADP-ribose)polymerase. Oncogene 12: 529-535

Casciola-Rosen L, Nicholson DW, Chong T, Rowan KR, Thornberry NA, Miller DK and Rosen A (1996) Apopain/CPP32 cleaves proteins that are essential for cellular repair: a fundamental principle of apoptotic death. J. Exp. Med. 183: 1957-1964

Chinnaiyan AM, O'Rourke K, Tewari M and Dixit VM (1995) FADD, a novel death domain-containing protein interacts with the death domain of Fas and initiate apoptosis. Cell 81: 505-512

Chinnaiyan AM, Orth K, O'Rourke K, Duan H, Poirier GG and Dixit VM (1996) Molecular ordering of the cell death pathway. Bcl-2 and Bcl-xL function upstream of the CED-3-like apoptotic proteases. J. Biol. Chem. 271: 4573-4576

Cifone MG, Roncaioli P, De Maria R, Camarda G, Santoni A, Ruberti G and Testi R (1995) Multiple pathways originate at the Fas/APO-1 (CD95) receptor: sequential involvement of phosphatidylcholine-specific phospholipase $C$ and acidic sphingomyelinase in the propagation of the apoptotic signal. EMBO J. 14: $5859-5868$

Enari M, Hug H and Nagata S (1995) Involvement of an ICE-like protease in Fasmediated apoptosis. Nature 375: 78-81

Gamen S, Marzo I, Anel A, Pineiro A and Naval J (1996) CPP32 inhibition prevents Fas-incuded ceramid generation and apoptosis in human cells. FEBS Lett. 390: 232-237
Gu Y, Sarnecki C, Aldape RA, Livingston DJ and Su M (1995) Cleavage of poly(ADPribose)polymerase by interleukin- 1 beta converting enzyme and its homologs TX and Nedd-2. J. Biol. Chem. 270: 18715-18718

Hannun YA (1996) Functions of ceramide in coordinating cellular responses to stress. Science 274: 1855-1859

Hasegawa J, Kamada S, Kamiike W, Shimizu S, Imazu T, Matsuda H and Tsujimoto Y (1996) Involvement of CPP32/Yama(-like) proteases in Fas-mediated apoptosis. Cancer Res. 56: 1713-1718

Hurwitz R, Ferlinz K and Sandhoff K (1994) The tricyclic antidepressant desipramine causes proteolytic degradation of lysosomal sphingomyelinase in human fibroblasts. Biol. Chem. Hoppe-Seyler 375: 447-450

Jayadev S, Hayter HL, Andrieu N, Gamard CJ, Liu B, Balu B, Hayakawa M, Ito $F$ and Hannun-YA (1997) Phospholipase A2 is necessary for tumor necrosis factor- $\alpha$-induced ceramide generation in L929 cells. J. Biol. Chem. 272: $17196-17203$

Kischkel FC, Hellbardt S, Behrmann I, Germer M, Pawlita M, Krammer PH and Peter ME (1995) Cytotoxicity-dependent APO-1 (Fas/CD95)-associated proteins form a death-inducing signaling complex (DISC) with the receptor. EMBO J. 14 $5579-5588$

Kroemer G (1997) The proto-oncogene Bcl-2 and its role in regulating apoptosis. Nat. Med. 3: $614-620$

Lazebnik YA, Kaufmann SH, Desnoyers S, Poirier GG and Earnshaw WC (1994) Cleavage of poly(ADP-ribose)polymerase by a proteinase with properties like ICE. Nature 371: $346-347$

Los M, van de Craen M, Penning LC, SchenkH, Westendorp M, Baeuerle P, Dröge W Krammer PH, Fiers W and Schulze-Osthoff K (1995) Requirement of an ICE Ced-3 protease for Fas/Apo-1 mediated apoptosis. Nature 375: 81-83

Mandal M, Maggirwar SB, Sharma N, Kaufmann SH, Sun SC and Kumar R (1996) Bcl2 prevents CD95 (Fas/APO-1)-induced degradation of lamin B and poly(ADPribose) Polymerase and restore the NF- $\kappa$ B signaling pathway. J. Biol. Chem. 271: 30354-30359

Medema JP, Scaffidi C, Kischkel FC, Shevchenko A, Mann M, Krammer PH and Peter ME (1997) Flice is activated by association with the CD95 death-inducing signaling complex (DISC). EMBO J. 16: 2794-2804

Mizushima N, Koike R, Kohsaka H, Kushi Y, Handa S, Yagita H and Miyasaka N (1996) Ceramide induces apoptosis via CPP32 activation. FEBS Lett. 395:267 271

Muzio M, Chinnaiyan AM, Kischkel FC, O'Rourke K, Shevchenko A, Ni J, Scaffidi C, Bretz JD, Zhang M, Gentz R, Mann M, Krammer PH, Peter ME and Dixit VM (1996) FLICE, a novel FADD-homologous ICE/CED-3-like protease, is recruited to the CD95 (Fas/APO-1) death-inducing signaling complex. Cell 85: 817-827

O'Donnell VB, Spycher S and Azzi A (1995) Involvement of oxidants and oxidantgenerating enzyme(s) in tumour-necrosis-factor-alpha-mediated apoptosis: role for lipoxygenase pathway but not mitochondrial respiratory chain. Biochem. J. 310: $133-141$

Pennington MW and Thornberry NA (1994) Synthesis of a fluorogenic interleukin-1 beta converting enzyme substrate based on resonance energy transfer. Pept. Res. 7: 72-76

Reed JC (1997) Double identity for proteins of the Bcl-2 family. Nature 387: 773-776 Rensing-Ehl A, Frei K, Flury R, Matiba B, Mariani SM, Weller M, Aebischer P, Krammer PH and Fontana A (1995) Local Fas/APO-1 (CD95) ligand-mediated tumor cell killing in vivo. Eur. J. Immunol. 25: 2253-2258

Schlegel J, Peters I, Orrenius S, Miller DK, Thornberry NA, Yamin TT and Nicholson DW (1996) CPP32/apopain is a key interleukin 1 beta converting enzyme-like protease involved in Fas-mediated apoptosis. J. Biol. Chem. 271: $1841-1844$

Schulze-OsthoffK, Krammer PHand Droge W (1994) Divergent signalling via APO-1/ Fas and the TNF receptor, two homologous molecules involved in physiologica cell death. EMBO J. 13: 4587-4596

Smyth MJ, Perry DK, Zhang J, Poirier GG, Hannun YA and Obeid LM (1996) prICE: a downstream target for ceramide-induced apoptosis and for the inhibitory action of Bcl-2. Biochem. J. 316: 25-28

Srinivasula SM, Ahmad M, Fernandes-Alnemri T, Litwack G and Alnemri ES (1996) Molecular ordering of the Fas-apoptotic pathway: the Fas/APO-1 like protease Mch5 is a Crm-A inhibitable protease that activates multiple Ced-3/ICE-like cysteine proteases. Proc. Natl. Acad. Sci. USA 93: 14486-14491

Strasser A, Harris AW, Huang DC, Krammer PH and Cory S (1995) Bcl-2 and Fas/ APO-1 regulate distinct pathways to lymphocyte apoptosis. EMBO J. 14:61366147 
Tepper AD, Boesen de Cock JGR, de Vries E, Borst J and van Blitterswijk WJ (1997) CD95/Fas-induced ceramide formation proceeds with slow kinetics and is not blocked by caspase 3/CPP32 inhibition. J. Biol. Chem. 272: 24308-24312

Tepper CG, Jayadev S, Liu b, Bielawska A, Wolff R, Yonehara S, Hannun YA and Seldin MF (1995) Role for ceramide as an endogenous mediator of Fas-induced cytotoxicity. Proc. Natl. Acad. Sci. USA 92: 8443-8447

Tewari M and Dixit VM (1995) Fas- and tumor necrosis factor-induced apoptosis is inhibited by the poxvirus CrmA gene product. J. Biol. Chem. 270: 3255-3260

Wagenknecht B, Gulbins E, Lang F, Dichgans J and Weller M (1997) Lipoxygenase inhibitors block CD95 ligand-mediated apoptosis of human malignant glioma cells. FEBS Lett. 409: 17-23

Weller M, Frei K, Groscurth P, Krammer PH, Yonekawa Y and Fontana A (1994) AntiFas/APO-1 antibody-mediated apoptosis of cultured human glioma cells. Induction and modulation of sensitivity by cytokines. J. Clin. Invest. 94: 954-964
Weller M, Malipiero U, Aguzzi A, Reed JC and Fontana A (1995) Protooncogene bcl-2 cDNA transfer abrogates Fas/APO-1 antibody-mediated apoptosis of human malignant glioma cells and confers resistance to chemotherapeutic drugs and therapeutic irradiation. J. Clin. Invest. 95: 2633-2643

Weller M, Trepel M, Grimmel C, Schabet M, Bremen D, Krajewski S and Reed JC (1997) Hypericin-induced apoptosis of human malignant glioma cells is lightdependent, independent of bcl-2 expression, and does not require wild-type p53. Neurol. Res. 19: 459-470

Weller M, Kleihues P, Dichgans J, Ohgaki H (1998) CD95 Ligand: lethal weapon against malignant glioma? Brain Path. 8: in press

Zhou Q, Snipas S, Orth K, Muzio M, Dixit VMand Salvesen GS (1997) Targetprotease specificity of the viral serpin CrmA. J. Biol. Chem. 272: 7797-7800 